\title{
DEFINING THE CONCEPT OF ARTS AND CULTURE IN HIGHER EDUCATION SYSTEMS IN INDONESIA
}

\author{
Pham Tran Minh Thi \\ Faculty of Social Sciences and Humanities, Ho Chi Minh University, Vietnam \\ Email: minhthiphamtran@gmail.com
}

\begin{abstract}
An understanding of art and culture has often been known by many Indonesian students and also the community. These two words are always a pair of words in the vocabulary of the languages and arts department in particular. There is art where the culture is, and vice versa culture is never released by the art. However, the definitions of "culture" and "art" require attention to be redefined towards supporting the new mental revolution held by the Indonesian government, and also to follow the world's advanced higher education system. In our opinion, it is better for the field of "culture" and the field of "art" to be understood as both becoming two scientific fields themselves. Then, understanding the arts in its position in relation to the cultural field from its elements related to awakening the cultural field becomes the need to develop a good arts education curriculum. Finally, Vietnamese character education is explained via the concept of mind relating to its culture and the characteristics of their nation. These problems will be discussed in this article.
\end{abstract}

Keywords: art, culture, mental revolution, art education

\section{MENDEFINISIKAN KONSEP SENI DAN BUDAYA DALAM SISTEM PENDIDIKAN TINGGI DI INDONESIA}

\begin{abstract}
Abstrak
Pemahaman tentang seni dan budaya sering dikenal oleh banyak siswa Indonesia dan juga masyarakat. Dua kata ini selalu merupakan sepasang kata dalam kosa kata departemen bahasa dan seni pada khususnya. Ada seni di mana budaya berada, dan sebaliknya budaya tidak pernah dirilis oleh seni. Namun, definisi "budaya" dan "seni" memerlukan perhatian untuk didefinisikan ulang untuk mendukung revolusi mental baru yang dipegang oleh pemerintah Indonesia, dan juga untuk mengikuti sistem pendidikan tinggi maju di dunia. Menurut pendapat kami, lebih baik bidang "budaya" dan bidang "seni" dipahami karena keduanya menjadi dua bidang ilmiah sendiri. Kemudian, memahami seni dalam posisinya dalam kaitannya dengan bidang budaya dari unsurunsurnya terkait dengan kebangkitan bidang budaya menjadi kebutuhan untuk mengembangkan kurikulum pendidikan seni yang baik. Akhirnya, pendidikan karakter Vietnam dijelaskan melalui konsep pikiran yang berkaitan dengan budaya dan karakteristik bangsanya. Masalah-masalah ini akan dibahas dalam artikel ini.
\end{abstract}

Kata kunci: seni, budaya, revolusi mental, pendidikan seni

\section{INTRODUCTION}

Many problems that mention the behavior and attitudes of students become an issue that is considered by many students in Indonesia.
Actually there is a solution available to reduce or prevent the problem emergency. One solution is to develop character education for students by following the mental revolution 
of the current Indonesian government. The arts education sector can also support a mental revolution campaign to develop character education for students in the same way as other fields of education. One of the world of education is functioning to awaken human attitudes and abilities. This article is produced from a review of elementary school, junior high and high school books; curriculum handbooks for 2006 and 2013; and analysis of papers from education and cultural experts in Indonesia and Vietnam.

Art and culture is one of the most important subjects in the Art Education Study Program, with a mixture of two arts and culture. The concept of art and culture was born and used widely. Not only in the Art Education Study Program, but also in community life. Most Indonesians continue to believe that art cannot be separated from culture, on the contrary culture cannot be separated from art. This is true but it is not right, because if you think about it, art is only related to culture, on the contrary culture is only related to art, and both are not related to other educational areas.

Then, what is important is if we think that art and culture are always one, we do not understand these two fields perfectly, because students only know the half-way, either the arts or culture alone in a subject. Therefore, students do not understand the system, structure or function of one area properly. In this article, it is necessary to think that as students in the Art Education Study Program in higher education in Indonesia, it is necessary to understand the difference between the two fields of art and culture, or to separate the concept of art and culture into two concepts individually.

In Vietnam, the arts and culture are understood as two separate fields of education that have special elements. Every understanding of culture has a special structural system. Understanding the concept of "culture" that follows Prof. Dr. Tran Ngoc Them can mention the cognitive culture of the people of Vietnam that can awaken the character of the Vietnamese nation and can also develop character education for the younger generation. In the history of
Vietnam until now there has never been a mental revolution like in Indonesia. That is because Vietnamese culture has character education values that are internalized with the life of the Vietnamese people. Character education in Vietnam includes education in daily life, both in the school environment, home environment, and community environment.

\section{DISCUSSION \\ Concept of Art and Culture Subjects}

Art and culture have become one of the most prevalent concepts in the field of art education. The concept is a compound concept created from two separate concepts, namely art and culture. Art is one of the results that have a high value of beauty, created by humans from experiences that come from interactions with the natural environment and social environment. According to the Big Indonesian Dictionary (KBBI), Art is: (1) the expertise to make quality works in terms of their refinement, beauty, and so on; (2) works that are created with extraordinary expertise, such as dance, painting, crafts. . In addition, art is also indicated as all human actions arising from living feelings and are beautiful, so that it can move the soul of human feelings (Ki Hajar Dewantara).

Culture is a concept that is difficult to define because it has many notions about the concept. Various parties have their own definitions. For example, the Department of Cultural Sciences from birth to the present day defines culture as an organic system that all tangible or intangible values are created and accumulated by humans in the process of interaction with the natural and social environment (Trần Ngọc Thêm , 1991). According to Ki Hajar Dewantara (Wien Pudji Priyanto, 2004), culture is the result of human creativity, taste, and behavior. Although there are many definitions of culture, most cultural definitions and concepts are inseparable from the very important role of human beings, and human relationships with the natural and social environment.

Regarding the position of art and culture, the important thing is that the relationship 
between art and culture is always related and it can be mentioned that art is the most easy to express its culture. According to Prof. Dr Phan Thi Thu Hien, that one of the art institutions whose institutions are fundamental is culture. What is clear is that art has a multidimensional interaction with culture. Art is a part of culture produced by humans or society (Wien Pudji Priyanto, 2004: 1). In Indonesia, there is a wellknown mind that art cannot be separated from culture. Conversely culture also cannot stand alone from art. Possible concept of art and culture can be created from there. According to the Big Indonesian Dictionary (KKBI), the concept of art and culture seems to be connected only by two fields, namely art and culture. This understanding is correct but it is not yet clear to define the concept.

If traced initially, the concept of art and culture originated from the curriculum in the education unit level (KTSP) in 2006 and is a subject in Indonesian schools. The concept originated from the education policy made by the Indonesian government, until it became a common thought in the minds of its people. Based on research on the history of primary school curriculum in Indonesia by S.Belen, from the National Education Research and Development Curriculum Center. The name of the subject of arts education changed to subjects of Art and Culture and Skills for levels elementary school, and the name of the art subject is mentioned Cultural arts for junior and senior high school levels.

The contents of the 2006 SBC compared to the contents in the previous curriculum, for example the curriculum in 2004 and 1994, the subject of cultural arts is called Crafts and Arts ", or in the 1984 curriculum called art education (Susilowati, 2017: 128). The new concept of art and culture was in the 2006 curriculum, and was used again in the 2013 curriculum. Based on the 2006 Curriculum general guidebook, the subject of Cultural Arts is a culture-based arts education. Giving the name of art and culture to the subjects of art and culture comes from the desire of Indonesian educational achievements of students, especially art education, it seems that the three initial principles in the curriculum unit level education in 2006, namely 1) Focusing on the potential, development, needs, and interests of students and students its environment; 2) Diverse and integrated; 3) Response to the development of art and other fields of education.

Therefore, in the 2006 curriculum given an aesthetic experience in the form of activities of expression and appreciation of art through approaches: learning with art, learning through art, and learning about art. Art and culture subjects will also foster and develop the ability to appreciate various Indonesian and foreign cultures. The most important goal is to help students enable the exploration of elements, principles, processes and techniques of work in the context of diverse cultural communities. In addition, in the 2013 curriculum, the subject of Art and Culture is a learning activity that displays aesthetic, artistic, and creative arts for students to achieve Indonesia's educational goals, namely: preparing an Indonesian to have the ability to live as a person and a faithful, productive citizen, creative, innovative and affective and able to contribute to the life of society, nation, state and in the world civilization arena.

However, the concept of art and culture is better understood to only show the arts, while the cultural part is not well considered. Thus, what is meant by Indonesian culture in daily conversation turns out to be showing more artistic results (Soekanto, 1980: 15). This is evidenced that many books on the subject of Culture and Art, Dance, Music, Fine Arts, Theater Arts say only about the skills of these types of arts and the cultural section related to Art is not stated or written only a little. For example, the Art and Culture book for Junior High School, MTs Class VII, semester 1 of the 2014 revised edition, by Eko Purnomo and friends, only mentions that the understanding, elements, skill techniques, etc. for each type of art, seems fine arts, dance, music, theater. In addition, a dance book class X-XII "for high school, written by Ari Subekti and Budiawan, from the Education Center, Ministry of National 
Education, in addition to providing ideas for composing dance branches, how to display or prepare dance performances and related field skills Other dance arts, this book also only mentions a number of issues connecting with cultural fields, such as the role of single dance in people's lives, or the role of dance work or the Chapter 11 section on appreciating foreign art.

The concept of culture in terms of art and culture is only understood as an aspect of inheritance that has been written in almost all the introductory parts of cultural arts books, namely "the learner is designed based on activities in a number of cultural and artistic domains that are lifted from the themes of art which are the nation's cultural heritage (Purnomo , 2014: 3). The issue has an impact on the minds of students and also Indonesian citizens in general, that the notion of "culture" is only related to art, and more dangerous the value of art is stronger than the value of culture or the field of art wider than the field of culture. When in fact, the two fields are likely to have the same freedom, can stand alone, and the important thing is the relationship between art and culture always interactively interactively.

Some alternatives to overcome these problemsinclude the subject of Artand Culture is recommended to change its name by separating it into two types of books, namely Citizen Art and Macanegara Art. This is important, bearing in mind that many foreign arts enter Indonesia every time. Then, if officers of the Indonesian Ministry of Education and Culture still want to take the name of the Cultural Arts subject, then the contents of the knowledge in these books can be added to a wider range of culture.

\section{Definition of "Culture" and Its Structure}

Culture is not only visible from the arts. The field is broader and has its own elements, and each element has a broad structure and teba. Culture is not only in the form of objects of art and various forms of art. Also in the form of attitudes, human behavior, ways of thinking, outlook on life, judgments about the good and bad, all of which include cultural understanding
(Soekanto, 1980: 15). Culture is one of the main objects studied in the area of cultural education (Culturology or Culture Studies). Starting from an Expert Edward Burnett Tylor who planted the first seeds of cultural understanding in 1971 in the book Primitive Culture until now there are mostly cultural notions created by experts in their respective fields with different aspects of their glasses. In Indonesia, there have been many experts who have gotten an understanding of the concept of culture. Including the description of cultural elements to the field of national cultural preservation and knowledge of foreign cultures. In addition, culture is all manifestations of the work of the human soul, both as individuals and in their relationships as members of society (Mangunsarkoro, 1951: 4). That also applies in the development of cultural education in Vietnam. Most students majoring in culture look for understanding concepts that are in accordance with their thoughts and relationships with the conditions of the natural and social environment. Every understanding of the concept of culture has a special structure and is in accordance with that understanding.

Now in Vietnam there is a famous cultural notion created by Trần Ngọc Thêm, head of the Ho Chi Minh State University science foundation. According to him, culture is an organic system that contains all the values of objects or not objects created and accumulated by humans in the process of interaction with the natural and social environment (Trần Ngọc Thêm, 1991). From this understanding, culture has three major branches, namely: cognitive culture, organizational culture, and cultural behavior. Each branch is divided into six small sections. In the branch of cognitive culture it divides into two small parts, namely cosmic and human cognitive culture. In organizational culture, community life and individual life; The third branch has a culture of behavior towards the natural environment and social environment. Culture has the characteristics of the system, values based on humanity and history (Sutiyono, 2014: 51). Based on these characteristics, culture can manage society, correct social standards, communication and 
education. The position of art includes a branch of cognitive culture.

\section{Vietnam's Traditional Culture as Character Education}

Throughout the development of Vietnamese history, since the ancestors to the present, there has never been a campaign of mental revolution, because the characteristics of the Vietnamese people have the same thoughts, namely: humanity (nhân), rules (lễ), morals (nghia), right thoughts (tri), charisma (tín). Five important traits of national character are learned in schools, from the past until now. Vietnamese character education is now carried out through two subjects, namely Moral (Đạo Đúc) at the Elementary School and Citizenship Education (Giáo dục công dân) in Junior High Schools and High Schools.

Actually character education in Vietnam is not only carried out in schools, but also carried out in the home, family and community. Even more special, the character education of the people of Vietnam is obtained through the intuition of folk songs. This song contains fairy tales that tell about character education. When the baby is born already listens to a folk song (hát ru) from his mother. This song is sung by the mother with the aim that it is easy to sleep fast and sleep well. In this folk song contains about the love of the nation of Vietnam. In addition, moral behavior such as how to behave with older siblings, parents, neighbors, and so on.

A mother often sings folk songs before her child before going to bed and the child hears good things every day. When a child grows up to become an adult, still follow the teachings in folk songs. Furthermore, he conducts personal behavior with good morals. The educational process carried out by a mother by singing folk songs, proves that the arts still function to build and develop the character of a human being (Noviyanti, 2017: 98). The five character traits mentioned above are available in Vietnamese culture since the ancestors as a habit of behavior among people in everyday life.
However, it was not written into an official theory until Confucius entered Vietnam via a thousand years of war and occupation. After a thousand years of Chinese colonialism, the Vietnamese people did not reject the stronger influence of the Chinese, and then took the good things out of the culture and created a culture that was uniquely Vietnamese by mixing local culture. Taking the theory of mind from a Confucius Expert and creating a unique culture in Vietnam is also one of the distinctive features of the Vietnamese nation's character, namely humanity and forgiveness. A young Vietnamese man is often taught with character education from elementary school through high school. Their efforts are aimed at making the nation of Vietnam a good nation, that is, having Vietnamese cultural characteristics.

The folk song has been recognized by the Educational, Scientific and Cultural Organization, United Nations (UNESCO) as a Cultural Heritage of Vietnam. Phu Tho Province has educated 62 artists and 101 classes for the people, not counting the various classes in schools and among youth and children. These are very valuable factors and should be appreciated for several years to preserve the folk song of Xoan. Xoan folk songs and folk songs performed by Xoan folk song teams and all Xoan folk song clubs ". In the city of Viet Tri (Phu Tho province) also held a program of performances of Xoan folk song singing among children which shows that Xoan folk song has been introduced not only among big people, but also among teenagers and children This is a form of preservation of folk songs, as well as a character education medium for children in Vietnam.

\section{CONCLUSION}

The concept of art and culture has become the understanding and thoughts that we are accustomed to, but that understanding is more directed to the field of art and forgetting the good influence of its culture. Art and culture. Art and culture together are also the creation of humans and are closely related. Then, from the cultural understanding in Vietnam, we carry 
our way of thinking and character education towards young people, their efforts to become good people have the same national love as the ability to awaken and improve the country of Vietnam into the future. Mental Revolution has never been held in Vietnam in its history because the mindset (traditional philosophical theory) of Vietnam has remained the same starting from the days of our ancestors until now, namely: Nhân (Human), Lễ (rule), Nghĩa (behavior) ), Trí (thinking which right), Tín (charisma) which remains sought after in daily life and in learning at school too. However, character education in Vietnam is still available through instincts that can be seen in terms of culture and culture art, as folk songs and the story, to moral subjects and subjects of citizens in schools.

\section{REFERENCES}

Subekti, Ari Subekti., Budiawan. 2008. Seni Tari. Penerbit: Buku Sekolah Elektronik (BSE).

Soekanto, Basuki (et al). 1980. Antropologi Budaya untuk SMA. Jakarta: Departmen Pendidikan dan Kebudayaan.

Purnomo, Eko (et al). 2014. Seni Budaya. Pusat kurikulum dan Perbukuan, Balitbang, Kemdikbud.

Purnomo, Eko (et al). 2014. Buku Guru: Seni Budaya. Pusat kurikulum dan Perbukuan, Balitbang, Kemdikbud.
Mangunsarkoro, S. 1951. Kebudajan Rakjat. Jogjakarta: Usaha Penerbit Indonesia.

Noviyanti, Siti Risa., Sutiyono, S. 2017. Bentuk, Perubahan Fungsi, dan Nilai-nilai Edukatif pada Musik Tari Japin Tahlul di Amuntai. Imaji: Jurnal Seni dan Pendidikan Seni, 15(1), 97-112.

Belen S. 2010. Sejarah kurikulum SD di Indonesia. Jakarta: Pusat kurikulum, Badan Penelitian dan Pengembangan Kementerian Pendidikan Nasional.

Priyanto, Wien Pudji. 2004. Model pembelajaran tari kreasi baru di padepokan seni bagong kussuddiardja, Yogyakarta. Program Pascasarjana. Universitas Negeri Yogyakarta.

Susilowati, Lusi., Sutiyono, S. 2017. Evaluasi Pelakasanaan Kurikulum 2013 pada Mata Pelajaran Seni Tari SMA Negeri di Sleman Yogyakarta. Imaji: Jurnal Seni dan Pendidikan Seni, Vol. 15, No. 2, 126 $-139$.

Sutiyono. 204. Developing Humanism Through the Teaching and Learning of Traditional Arts in Indonesia. Asian Journal of Management Sciences \& Education Vol. 3(2), 49-56.

Them, Tran Ngoc. Definisikan tentang Budaya. 2013. Ho Chi Minh: su-isu ilmu sosial dan kemanusiaan: khusus pendidikan ilmu budaya.

Hien, Phan Thu 2005. Kebudayaan Seni sebagai cabang pendidikan ilmu budaya. Ho Chi Minh 